\title{
The Fiqh of Pandemic: The Arguments and Practices of Worship at the Al Akbar National Mosque in Surabaya
}

\author{
$1^{\text {st }}$ Muhammad Alwi Al Maliki ${ }^{1}, 2^{\text {nd }}$ Ahmad Arif Masdar Hilmy ${ }^{2}, 3^{\text {rd }} \mathrm{JM} \mathrm{Muslimin}^{3}$, \\ $4^{\text {th }}$ Kamarusdiana ${ }^{4}, 5^{\text {th }}$ Asmawi $^{5}, 6^{\text {th }}$ Asriati $^{6}$ \\ \{muhammad_maliki19@mhs.uinjkt.ac.id ${ }^{1}$, arivmasdar@gmail.com ${ }^{2}$, jm.muslimin@uinjkt.ac.id ${ }^{3}$, \\ kamarusdiana@uinjkt.ac.id ${ }^{4}$, asmawi@uinjkt.ac.id ${ }^{5}$, asriy ati@uinjkt.ac.id ${ }^{6}$ \} \\ Sy arif Hiday atullah State Islamic University of Jakarta, Indonesia ${ }^{1456}$, Sunan Ampel State Islamic ${ }^{3}$ \\ University of Surabay a, Indonesia ${ }^{2}$
}

\begin{abstract}
This research examines the arguments and practices of worship during the COVID-19 pandemic at the Al Akbar National Mosque (MAS). The research data was obtained through the method of literature study and interviews of several participants who carried out congregational worship at the mosque. The data analysis method used is descriptive-analytical with the ușülì approach. Based on the research results, argumentatively the implementation of worship in MAS is based on the principle of dar'u mafāsid muqaddam 'alā jalb al-mașālih which places human safety as a priority (salus populi suprema lex) and also suitable to the al-dhari'ah theory. In practice, the MAS management has implemented fourteen prayer protocols properly to create comfort during worship. However, several aspects need to be improved in the future.
\end{abstract}

Keywords: Fiqh, Pandemic, Worship, Al Akbar National Mosque

\section{Introduction}

At the end of 2019, the world was hit by the COVID-19 virus pandemic, which until now has had a significant impact on all aspects and lines of life. The pandemic has claimed millions of lives in various parts of the world, including Indonesia. Therefore, the government pays great attention to it. Various attempts have been made by the government to overcome this problem. One of them is by issuing a Large-Scale Social Restriction (PSBB) policy to break the chain of transmission of the virus.[1]

The COVID-19 pandemic has succeeded in changing the existing order, including the order of Muslim worship practices. In Indonesia, this has led to various religious polemics, especially in Islam, which in some cases of worship necessitates the gathering of many people, such as in the practice of the five daily prayers, Friday prayers, Eid al-Fitr prayers, Eid alAdha, and so on. Regarding this, various responses emerged from several groups, both individually and on behalf of Islamic institutions such as the Indonesian Ulama Council (MUI), Nahdhatul Ulama (NU), Muhammadiyah, and so on.

These various views seem to represent the different views and ways of behaving of Muslims in facing and responding to the COVID-19 pandemic to religious practices. Some think that the practice of worship must continue to be carried out properly and others consider that in a pandemic that is still not resolved, it is better not to practice worship properly and 
take a new form that is more in line with current conditions. This certainly has an impact on decision-making by takmirs and mosque management boards throughout Indonesia, regarding which steps to take given the differences as previously mentioned.

Al Akbar National Mosque (MAS) is one of the mosques that are the center of civilization for Muslims in Indonesia. Known as the second-largest mosque in Indonesia, MAS is one of the mosques that influences other mosques, especially in East Java. The mosque even received recognition from the Nabawi Mosque in Mecca for successfully carrying out Friday prayers for the first time during the pandemic by implementing strict worship protocols. [21]

During the COVID-19 pandemic, several policies had been taken by MAS managers in response to the current situation. Such as the policy of shaf distance in congregational prayers, procedures for purifying, the attributes that must be used when performing prayers at MAS, and so on. This certainly does not result from space. A thorough study of various aspects is carried out so that decisions can be made for the benefit of the people.

The existence of a circular regarding the granting of permission to MAS to perform Eid al-Fitr prayers in the congregation turned out to be a byword in the community. There were many pros and cons to the permit because at that time the city of Surabaya had the status of the red zone. Due to the existing polemic, the circular was later revoked. The change in decisions taken during the short period certainly made the public even more confused, considering that previously MAS had held Friday prayers and tarawih in the congregation. Not a few of the people then think whether the health protocol that has been implemented is inadequate and seems "the important is there".

There has been a lot of scientific research on the COVID-19 virus pandemic. Various aspects that have been affected have been widely analyzed, such as from the aspects of health, education, administrative policy to law and politics. As for the context of worship, especially in the issue of carrying out congregational worship, several previous studies have been conducted. As was done by Syamsuddin (2020) concerning "Relief (Rukhshah) to Eliminate Friday Prayers and Jama'ah Prayers and the Obligation to Obey Ulul Amri".[2] Likewise, research on the involvement protocol of the distance between saf in prayer conducted by Agus Nasir (2020)[3] and Eko M. Hasibuan-Muhammad Yusram (2020).[4] Besides, there is also research on "The Use of Face Masks During Prayer as a Step to Prevent the Coronavirus Outbreak COVID-19" by Syandri and Fadlan Akbar (2020).[5]

Based on several presentations and previous research, it can be understood that the is sue of implementing worship is one of the crucial aspects during the pandemic period. Differences of opinion about it provide opportunities as well as challenges for mosque managers in Indonesia, especially in making decisions regarding the implementation of worship. MAS, as mentioned earlier, has been recognized for its competence in responding to is sues of worship during the pandemic period. Therefore, research on the implementation of worship during the pandemic period in MAS is necessary. This study aims to answer questions about how the arguments and practices of worship during the pandemic at the Al Akbar National Mosque.

\section{Research Methodology}

This research is a qualitative study that discusses the arguments and practices of worship during the pandemic at the Al Akbar National Mosque (MAS). The data in this study were obtained using a literature study and interviews. 
A literature study is a method of collecting data in the form of written facts and stored in document form.[6] In this research, this method is used to collect written data in the form of narrative and visual spread on social media. Meanwhile, interviews are used to obtain the latest data from worshipers, both from mosque managers and congregations who perform worship at the MAS.[7] In this study, interviews were conducted using a purposive sampling technique by asking certain questions according to the research objectives.[8]

After the data collected, then it is analyzed using the $u s \underline{u} l \bar{\imath}$ approach. There are many theories in this approach. This research using the theory of al-dharīah. The use of the terminology al-dharī'ah refers to the opinion of Wahbah al-Zuhailiy by considering the use of the theory of fath al-dharí'ah in addition to sadd al-dharī'ah which is more commonly known.[9]

\section{Finding}

\subsection{The Pandemic in Islam}

The spread of the Coronavirus has now attacked various countries around the world, including Indonesia. Corona Viruses (CoV) or also known as COVID-19 is a new type of virus that began spreading in 2019 , where this virus had never previously been found to attack humans. This case first occurred in Wuhan, China, with symptoms that were not much different from the flu, namely coughing, fever, shortness of breath, weakness, and loss of appetite. It's just that the difference is that the Coronavirus spreads and develops faster so that sufferers can be infected more severely and body organs can be more susceptible to damage. Therefore, on March 11, 2020, this virus was designated by the World Health Organization (WHO) as a global pandemic.

The spread of the Coronavirus is mentioned through contagious. Contagion is a term related to an infection that can spread rapidly in a tissue. This means that the spread of the coronavirus is caused by elements that are connected in a network, each person in a short time can transmit the infection to one another. This virus attacks a person regardless of age. Handling of this virus must be overcome as soon as possible, given its relatively easy spread, because it is only through close contact with sufferers.[10]

The increase in the number of corona positive patients and the ups and downs of the impact that occurred made the Government begin to switch to the term New Normal or New Normal. Since March 12, 2020, New Normal is a method introduced by WHO to be able to control human activities after a period of handling the Coronavirus. From there, the Government began to loosen restrictions and reopen public spaces to stabilize the economic aspect, of course, accompanied by strict health protocols. The houses of worship which were initially closed, in the new normal era, have begun to reopen with a new layout and concept.

Reflecting on the history of Islam itself, a pandemic can be interpreted into two models, namely, disaster and illness. Disasters here are closely related to the decrees of Allah SWT, meaning that calamities that occur in this world have been predetermined, even before Prophet Adam. lowered on earth. The occurrence of a disaster has certainly been adjusted to all the strengths and abilities of the people.[11] The meaning of a pandemic in the form of illness is a form of dissolving the sins committed by humans themselves. Remembering that Allah SWT gives a disease not only because of punishment but also as a means to repent to Allah SWT.[12] 
Is lam has described that calamities are true and will happen on the determination of Allah SWT. This is by the words of his letter al-Hadid verse 22:

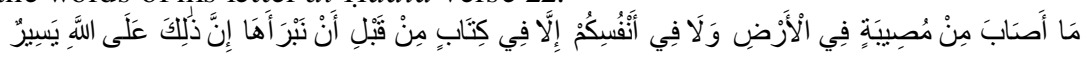

Apart from that in a hadith, the Prophet Muhammad SAW. also mentions:

$$
\text { اصناب الله بك }
$$

Based on the hadith above, it is understandable that Allah SWT has established a path or guidance that can lead to truth. That way, the calamity that is revealed later is part of a path or a guide so that humans are always on the right path.[11]

Even so with the meaning of illness in a pandemic, which is recorded in the hadith of the Prophet:

$$
\text { ما من مصيية تصيب المسلم الاكفر الله بها عنه حتى الشوكة يشاكها }
$$

The pain that has been assigned by Allah SWT to humans is motivated by the immoral sins he has committed so that when he is sick, a sign of the sins attached to him is being removed by Allah SWT. Even his sins are not only being washed away, but he is also being elevated by Allah SWT.[13]

Pandemic times have also been experienced by Muslim communities in Damascus and Egypt. When a pandemic occurs, the Government instructs its citizens to pray in the field. However, the number of victims increased because of the instructions. Indeed, on the one hand, the hadith records that praying and asking forgiveness from Allah SWT is a way to be kept away from a punishment:

$$
\text { يقالسحار صله عز وجل إني لأهم باهل الأرض عذابا فاذا نظرت إلى عمار بيوني و المتحائبين لي والمستغفرين }
$$

Allah SWT said: "Verily I intend to bring down punishment to the inhabitants of the earth, so when I see people who enliven My houses, who love each other because of me, and people who ask forgiveness at dawn, then I take away the punishment. it's from them."

But on the one hand, the hadith also instructs us to stay away from people who are infected with infectious diseases:

"Flee from the leper, as thou shalt flee from the lion."

$$
\text { فر من المجذوم فرارك من الأسد }
$$

When examining the contents of the two hadiths above, Muslims become confused because on the one hand we are encouraged to ask for forgiveness and enliven the mosque, but on the other hand, we also have to avoid people who are infected with infectious diseases. Remembering when Muslims are gathering together in the mosque to pray, at the same time they don't know anyone who has an infectious disease, because the condition of the mosque is busy and it is difficult to identify one by one.

The existence of two models of the meaning of a pandemic in Islam, coupled with the two hadiths above, further provides an understanding that Muslims should not necessarily interpret a pandemic as a decision and a test from Allah SWT alone, where a pandemic can be finished by accepting, being patient, without any effort. anything. More than that, Muslims must be able to catch that the pandemic was revealed so that they can improve themselves and try to fight for the next life.

In Indonesia, the Indonesian Ulama Council (MUI) through its fatwa No. 28 of 2020 concerning Procedures (Kaifiat) and Eid Al-Fitr Prayers During the COVID-19 Pandemic, allowing congregational prayer while maintaining health protocols and preventing transmission. Based on this fatwa, the East Java Provincial Government permitted to carry out Eid congregational prayers at the Al-Akbar National Mosque (MAS). However, not long after the permit was granted, the East Java Provincial Government revoked the permit it had issued again, this is of course due to the polemic that occurred in the community. 


\subsection{The Worship During Pandemic at Al Akbar National Mosque in Surabaya}

Al Akbar National Mosque (MAS) is one of several mosques that were responsive during the COVID-19 pandemic. Several policies have been carried out by the management in response to the dynamics of social change that occurred due to the pandemic. Some of the things that have been in the spotlight so far are the decision to continue carrying out congregational worship at the mosque, both in the implementation of the Fardu prayers five times a day, Friday prayers every week to the Eid al-Adha prayer procession. As for the implementation of the Eid Al-Fitr prayer, several extra considerations cause its implementation to be canceled for the public.

Since the government established the COVID-19 virus as a National pandemic and implemented the PSBB, the management has conducted several policy evaluations based on appeals from both the national and regional governments and religious institutions such as the Indonesian Ulema Council (MUI), Nahdlatul Ulama (NU) and Muhammadiyah in East Java. The evaluation resulted in a decision to continue carrying out congregational worship by implementing strict worship protocols to maintain religious morale (hifz al-dīn) and to protect the soul (hifz al-nafs). According to Kholiq Idris, the current pandemic cannot be addressed from one side only. Both the religious side and the social side must be addressed in a balanced manner. Therefore, the decision to continue carrying out congregational worship with this strict protocol was taken based on the principle of - dar'u al-mafāsid muqaddam 'alā jalb almașālih. [22]

Furthermore, Helmy M. Noor stated that the decision did not come from space. The decision was based on the philosophical values and enthusiasmcontained in the motto "Ibadah Yes, Disiplin Yes, Panik No" Commitment to realizing this motto makes MAS continue to practice worship by implementing fourteen strict protocols. Some of the protocols include checking body temperature when entering the prayer room, entering through the sterilization booth, wearing a mask when praying, occupying the cross-section (zigzag) $2.5 \mathrm{~m}$ apart that has been prepared. According to him, this strict protocol was enforced to create a comfortable and safe atmosphere of worship amid a tense pandemic. [21]

Regarding the implementation of the worship protocol, several MAS congregations responded positively. They said that the existence of worship protocols made their worship calmer and more comfortable so that they could merit without being overwhelmed by fear and worry about contracting the virus. This is as stated by Wildan. [23] According to him, the protocol applied by the mosque management has been good and makes it calm when worshiping. On different occasions, Kiki [24] and Faiz [25] also conveyed the same thing after carrying out congregational prayers at MAS.

Furthermore, according to Eko, the worship protocol is legally mandatory because it acts as an intermediary in protecting worshipers from being exposed to the COVID-19 virus. Starting from checking body temperature to cross-shafting (zigzag) $2.5 \mathrm{~m}$ apart and using masks when praying. Everything must be done to maintain and protect the congregation to stay safe and comfortable. [26] The same thing was also stated by Warnoto, he said that how could the congregation be able to worship calmly, solemnly, and comfortably when physically and psychologically filled with fear. [27]

Hilmy shared a different opinion. He said that the protocol that had been implemented was good, but there were still some deficiencies in practice in the field. According to him, the management did not pay attention to the volume of the congregation when entering the 
mosque area, so there was a long queue when checking body temperature, especially during Friday prayers. This made the line of pilgrims queuing barely far away. The potential for virus transmission occurred at that time. [28]

The same thing was expressed by Mahsun. He commented on the use of masks during prayers. According to him, not all worshipers know about the use of masks in question. For him, the use of masks has the potential to invalidate their prayers. This is because there is a possibility that the congregation wears unholy masks that will affect the validity of their prayers.[29] Even so with Najih. A person who feels uncomfortable with the implemented protocol. He admitted that he felt uncomfortable when he had to pray at a distance that was quite far from one another. For him, the $2.5 \mathrm{~m}$ distance was too far to make him feel uncomfortable. Besides, the distance is far enough that the mosque cannot accommodate many people. As a result, some people were forced to pray in the hot grounds of the mosque and made their skin blister. [30]

\subsection{The Epistemology of $A l$-Dhari’ah}

In general, al-dharī'ah is the equivalent of the word al-wasillah which means road, means, facilities.[14] Wahbah al-Zuhailiy states etymologically that al-dharīah is a means of conveying or facilitating the achievement of something. Based on this definition, he mentioned that there are two kinds of al-dhari'ah. First, the prevention of using the road or means when it leads to mafsadah (sadd al-dharī'ah). Second, affirmation to use the path or means when it leads to benefit (fath al-dharī'ah). In this scope, al-dharī'ah means neutral so its use depends on how al-dharī'ah functions and results.[9]

Etymologically, Sadd al-dhari'ah is a combination of two words that have the status of mudāf and mudäfilaih. The word sadd means to close, while dharí'ah means media, means, or road. In terms of terminology, it means the inability to use a path because it can lead to damage.[9] For example, adultery is haram, so looking at a woman's genitals that can lead to adultery is also haram.

Sadd al-dharī'ah can be called a method that is preventive to guard against the possibility of damage and things that lead to negative impacts. In Islam, one of the objectives of the law is to create benefits and prevent damage. Therefore, if there is an act which is permissible to do, but is suspected of leading to damage, then the path to that action must be closed. The basis used is the rule:

$$
\text { كل أمر يتذرع به إلي محظور فهو محظور [15 }
$$

The position of sadd al-dharī'ah as one of the methods in determining sharia makes the scholars differ in opinion, Imam Malik and Imam Aḥmad adhere to sadd al-dharī'ah a lot, while Imam Shäfi'i and Imam Abu Hanīfah are less adhering to the method. although both also do not reject sadd al-dharī'ah as a whole and do not recognize it as an independent argument. According to the two, this sadd al-dhari'ah is included in the method they have determined, namely qiyās according to Shāfi'i and istị̂sān according to Abu Ḥanīfah.[16]

The basis used by Imam Mālik and Imam Ahmad is the word of Allah SWT in Sura alAn'ām verse 108:

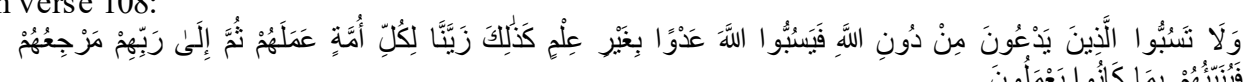

In contrast to the case with Imam Shāfi'i and Imam Abu Hanīfah who can accept sadd aldhari'ah as a method of solving problems in Islamic law if the mafsadah aspect is certain to occur, or at least is a strong presumption (ghaliba al-zan).[17] 
As for some literature $u s \underline{u} l$ al-fiqh, Al-dharī'ah by some scholars is only understood as something identical to closing the path that leads to mafsadah. Therefore, the sadd al-dharí' $a h$ theory is more popular than fath al-dhari' $a h$. Both of them are closely related to each other. In this regard, al-Qarāfi stated:

$$
\text { إعلم أن الذريعة كما يجب سدها يجب فتحها وتكره وتتدب وتباح فإن الذريعة هي الوسيلة فكما أن وسيلة المحرم }
$$

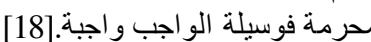

"So know that al-dhari'ah as obliged to close it, it is also obligatory to open it, and sunnah (to open it), and makruh, and mubah. (This applies so,) because in fact, al-dhari'ah is wasilah (intermediary). So just as wasilah an act that was haram was haram, wasilah an obligatory act was obligatory."

In line with al-Qarāfi, Ibn al-Qayyim al-Jawziyyah also stated that the concept of aldhariah is not only related to blocking ways but has a more general scope. He said:

الذريعة هي ما كان وسيلة وطريقا إلي الثيء

Furthermore, regarding the existence of fath al-dharī'ah, based on some of the statements of these scholars, it can be understood that the position of it in the istinbātal-ahk $\bar{a} m$ method is not in a position to determine the initial law. However, its position is based on the circumstances that affect it. In other words, fath al-dharī'ah can apply if there is a greater benefit that is realized from opening a path or means to something else. in this regard, Ibn Taymiyyah stated:

$$
\text { مفسدة كان منهيا لسد الذريعة لا لأنه مفسدة في نفسا, يشرع إذا كان فيه مصلحة راجحة ولا تفوت المصلحة لغير }
$$

"Something that is prohibited based on the sadd al-dhari'ah method, not because the original law is haram (li dhätihi), it is permissible to do it if there is greater benefit in it and it does not cause other greater dangers."

Ibn Taimiyah's explanation is not only the basis for the implementation of the fath aldhari'ah method but also affirms that it does not change the original law that was enforced. In the sense that this method is not allowed to justify what is haram from the origin.

\section{Discussion}

\subsection{The Analysis of Arguments for the Implementation of Worship at the Al Akbar National Mosque in Surabaya}

Starting from the release of a fatwa by the MUI, the mosque managers in Indonesia temporarily closed all access and religious practices. Even so, the management of the Surabaya Al Akbar Mosque (MAS) decided to follow the recommendation from the Government, namely to also close the temporary mosque from all forms of worship activities and practices. This decision was taken to break the chain of the spread of COVID-19, which until now has not found a vaccine. The tendency to use so that prevention of danger must take precedence overtaking advantage, as the Islamic legal maxim:

$$
\text { درء المفاسد مقدم على جلب المصالح }
$$

Decision-making made by MAS managers when analyzed using the uṣulli approach is by the sadd al-dhari'ah method, where the purpose of a law is of course to realize the benefit of the people. Therefore, efforts are needed to always protect and prevent danger. When the negative impact is seen, such as the potential for the spread of the virus to become apparent and has already claimed many victims, then any means that can spread the virus must be closed. The facility in this case is the practice of worship carried out jointly and facilitated by the mosque, including the MAS, which must be temporarily stopped. Remembering that we as 
humans should take care of ourselves, as well as to take care of others around us. This is as stated in Islamic legal maxim:

$$
\text { لا ضرر و لا ضرار. }
$$

As long as the MAS is closed for up to four weeks, this does not stop this mosque from carrying out the function of the mosque itself. The management takes strategic policies to continue to carry out the function of the mosque as a place of worship. Starting from continuing to carry out the Fardu prayer five times a day, Friday prayers, and tarawih prayers in congregation, only limited attendance is allowed from the internal management of the MAS itself. The reason why this policy must be implemented is that the mosque is the spirit of Islam so that if the mosque does not practice worship at all, this spirit may disappear.[31]

If we look closely, the policy of keeping the mosque alive by the MAS manager is a step to keep the mosque as having its previous functions and benefits. The existence of a condition that can re-establish the existence of the mosque must be supported and should not be closed, things like this can be leaned through the fath al-dharī'ah method. So that the greater benefit, namely the spirit of Islam through the existence of the mosque can be maintained. In this way, safeguarding the spirit of religion (hifz al-dinn) and the safety of the soul (hifz al-nafs) can be realized together. Maintaining religious spirit through the implementation of the five daily fardu prayers which are devoted to internal MAS managers. Meanwhile, mental preservation through temporary closure of MAS from the general public is as recommended by the Government, this is also by the Islamic Legal Maxim:

تصرف الامام على الرعية منوط بالمصلحة

Safeguarding religious spirit (hifz al-dīn) without being accompanied by efforts to preserve the safety of the soul (hifz al-nafs) is also not good to justify, as recently happened in Hagia Sophia, Turkey. In the news, it was stated that Hagia Shopia had become the new cluster of COVID-19, this was because there were 500 Friday prayer worshipers who tested positive for COVID-19, where the implementation of Friday prayers was attended by 350 thousand worshipers. The main causes are the lack of strict application of health protocols and a lack of awareness from the public. Until now, the number of positive cases of COVID-19 has continued to increase since Hagia Shopia was reopened as a mosque.

The general public has heard a lot about permitting the East Java Provincial Secretary to MAS to carry out Eid congregational prayers so that the managers of other mosques also decided to carry out Eid prayers in congregation. As a result, a polemic appeared in the community, and the regional secretary finally revoked the permit. After being confirmed, the contents of the permit stated that only those who were allowed to attend the MAS area were in good health. Due to the large number of people who took refuge without reading the full contents, noise could not be avoided.

Entering the new normal period, the MAS management dared to start to open the mosque so that worship practices could be carried out again, namely in the last ten days of the month of Ramadan, starting to hold Friday and Tarawih prayers in congregation, then followed by the five daily prayers, and Eid al-Adha prayers with the number of worshipers are quite large. By implementing strict health protocols, the MAS management argued that the practice of worship had returned to normal and the general public could worship comfortably again.

The argument mentioned above was built with careful preparation, considering that the implementation of Eid al-Adha prayers will certainly be attended by a large number of worshipers. The people who wish to perform Eid al-Adha prayers at MAS must first register online. Then the MAS manager determines the date for each congregation to take the id card as the key to enter MAS. The given id cards are divided into several color groups, where the 
color that is owned determines the position of the Eid al-Adha prayer later. The scheduling of taking ID cards and giving different colors is intended to minimize crowds.

The existence of careful preparation when it comes to holding religious practices in this new normal era gives us an understanding that MAS is indeed feasible and ready to implement strict health protocols. This can also be used to ward off people's perceptions of MAS's unpreparedness in holding religious practices, considering that the previous Eid prayer had been canceled. That way, people no longer need to be confused and worried when they are and worship at MAS.

When analyzed using the $u s \underline{u} l i$ approach, the arguments issued by MAS administrators can be classified as using the fath al-dharí'ah method in finding the best solution to this pandemic. Due to the absence of a vaccine and its enormous impact in various sectors, the Government must begin to reopen several public spaces that were initially closed. Based on this, places of worship can also be reopened with strict health protocols. The reopening of MAS to carry out worship practices was also followed by other mosques in East Java. So that the management's decision to reopen MAS is considered to be of benefit because other mosques can imitate the health protocols implemented by MAS.

In using the fath al-dharī'ah method, of course, one must not forget that the reason for reopening the facility or road that was originally closed is because there is a greater benefit that can be achieved. Therefore, MAS managers have a big role and responsibility for the implementation of the fourteen protocols that have been announced, considering that in addition to breaking the chain of the spread of COVID-19, many mosques base their policies on policies taken by MAS managers. The effectiveness in implementing the fourteen existing protocols rests on the shoulders of each person assigned by the MAS administrator. The Prophet Saw. has given a warning in his statements:

\footnotetext{
"Do not collect a sick camel for a healthy camel." (Bukhari and Muslim)
}

\subsection{The Analysis of Practices for the Implementation of Worship at the Al Akbar National Mosque in Surabaya}

In general, the practice of carrying out wors hip at the Al Akbar National Mosque has been good and meets the standardization of worship protocols determined by the Ministry of Religion. Fourteen existing protocols are well implemented. However, as stated in a saying that no ivory is not cracked. Even so with the adage "idhā tamma al-amru badā naqșuhu", that when everything which is finished, the flaws will appear.

This section discusses three of the fourteen prayer protocols that have been determined by the MAS administrator. The three protocols are queuing when checking body temperature, crossing shaf within $2.5 \mathrm{~m}$, and using masks in prayer. The three protocols were chosen because they have a strong correlation with two main as pects that are considered in the policy of implementing congregational prayer, namely the sacred aspect of congregational worship and the aspect of mental safety. Besides, these three protocols were chosen because there were several obstacles in practice in the field.

First, about queuing to check body temperature before entering the prayer room. As stated in the Circular of the Minister of Religion, one of the health protocols that must be applied is to check body temperature before entering a house of worship. This needs attention because one of the signs of a person exposed to the Covid-19 virus is a body temperature above 37.5 Celsius. One thing to note is that the increase in the volume of people who come to pray on Friday prayers is more than the five daily prayers. This is no less important to note because the 
purpose of checking body temperature is to prevent transmission of the virus in places of worship. If the increase in the number of people is not considered, it will create another danger, namely long queues which also have the potential to become a means of transmitting the virus.

If this happens, then as mentioned by Ibn Taymiyah, that fath al-dharī'ah cannot be applied to something that creates a new mafsadah even though it is seen as bringing maș lahah in its implementation. He said:

يشرع إذا كان فيه مصلحة راجحة ولا تفوت المصلحة لغير مفسدة راجحة.

"It is permissible to do it if there is greater benefit in it and it does not cause other greater dangers."

The impact that is caused when the queue becomes the spread of the Covid-19 virus, the implementation of congregational prayers changes the law to become makruh and even haram is carried out according to what al-Qarafi said:

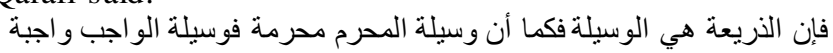

"(This applies so,) because in fact, al-dharī'ah is wasilah (intermediary). So just as wasilah an act that was haram was haram, wasilah an obligatory act was obligatory."

Second, about the cross-section of $2.5 \mathrm{~m}$. This section does not analyze the legal provisions of the application of the cross rows because they have been thoroughly discussed in the two previous studies. The shaf policy is one of the worship protocols implemented by the management to protect and protect people who worship at MAS.

Argumentatively it is by the principles of jalb al-mașālih and dar'u mafâsid. Besides that, as has been reviewed in two previous studies, there is an opinion of the scholars who allow this if it aims to bring a sense of security and comfort and keep people praying from the dangers that may occur. Even according to the group of scholars of the shāfi'iyyah thought this is also allowed in normal circumstances.[4] However, in practice, it seems that the manager needs to review existing policies. As stated by one of the participants, the $2.5 \mathrm{~m}$ distance is too wide for physical distancing, thus reducing the ration for prayer places. This resulted in many people praying in the courtyard of the mosque in a hot condition and some of them had their skin burned and blistered. And if that is the case, then as mentioned earlier, the law of congregational worship that was previously sunnah can turn into makruh because it endangers the bodies of the perpetrators.

Third, regarding the use of masks in prayer. Like the second point, this point does not intend to analyze the legal provisions on the use of masks in prayer because it has been discussed in previous research. Even so, the policy of using masks is also one of the efforts to realize the mental guarding of people who perform worship at MAS so that they are not exposed to the COVID-19 virus.

The legal provisions for the use of masks in prayer are closely related to the concepts of $a l$ maqāșid and al-wasāil. As mentioned in previous studies, the law of origin for use is makruh tanzih in prayer. This is based on the hadith of the prophet Muhammad SAW which prohibits friends from closing their mouths when praying. But then the original law changed because there was a change in 'illat, namely the urgent need to maintain the safety of the soul. In this context illat is manifested to avoid transmission of the COVID-19 virus through the respiratory system. Therefore, covering the nose and mouth area with a mask is a necessity because it is urgent (darürat). This is as in the Islamic legal maxim:

$$
\text { الحاجة قد تنزل منزلة الضرورة والضرورة تبيح المحظورات }
$$

However, the change of 'illat' cannot be used as a final decision to change the law on wearing masks. Other dimensions must be considered. This is as stated earlier that just focusing on maintaining the safety of the soul without paying attention to the sacredness of 
worship is not the right decision. The two, aspects of guarding religious spirit and mental safety must be considered in a balanced manner.

As for practice in the field, the mask use protocol in MAS has been implemented quite well. Many people who worship at the mosque have also responded positively. However, there are flaws in the protocol. This is about the importance of an appeal to use a holy mask. The sanctity aspect of a mask is no less important than the order to use it so that it does not catch the virus. This is important to understand for all people who worship at MAS because instead of getting the reward of worship and surviving the spread of the virus, their worship is not accepted because the masks used are not holy. Therefore, this aspect needs to be conveyed massively considering that the people who worship at MAS come from various backgrounds so that some of them have the potential to not know the aspects of the sanctity of masks if they are not advised before.

Acknowledgments. Thanks to Dr. JM Muslimin, MA who was willing to guide and become a mentor in this research process. Thank you also to all administrators of the Al Akbar National Mosque Management Executive Board who are willing to be interviewed. Hopefully, this research can be useful. 


\section{References}

[1] "Inilah PP Pembatasan Sosial Berskala Besar untuk Percepatan Penanganan Covid-19," setkab.go.id, 2020. [Online]. Available: https://setkab.go.id/inilah-pp-pembatasan-sosial-berskalabesar-untuk-percep at an-penanganan-covid-19/. [Accessed: 04-Aug-2020].

[2] Syamsuddin, "Keringanan (Rukhshah) Meniadakan Shalat Jumat dan Shalat Jama'ah serta Kewajiban Menaati Ulul Amri," Al- 'Adl, vol. 13, no. 2, pp. 165-184, 2020.

[3] A. Nasir, "Social Distancing Dalam Saf Salat Berjamaah (Perbandingan Ulama dalam Mazhab)," Maz. J. Perbandingan Agama, vol. 2, no. 1, pp. 29-36, 2020.

[4] E. M. Hasibuan and M. Yusram, "Hukum Salat Berjemaah Di Masjid Dengan Saf Terpisah Karena Wabah Covid-19," BUSTANUL FUQAHA J. Bid. Huk. Islam, vol. 1, no. 2, pp. 106-124, 2020, doi: 10.1093/trstmh/traa025.1.

[5] S. Syandri and F. Akbar, "Penggunaan Masker Penutup Wajah Saat Salat Sebagai Langkah Pencegahan Wabah Coronavirus Covid-19," SALAM J. Sos. dan Budaya Syar-i, vol. 7, no. 3, 2020, doi: $10.15408 /$ sjsbs.v7i3.15105.

[6] S. Soekanto, Pengantar Penelitian Hukum. Jakarta: UI-Press, 2010.

[7] C. Nurboko and A. Ahmadi, Metodologi Penelitian. Jakarta: Bumi Aksara, 1997.

[8] Sugiyono, Metode Penelitian Kuantitatif, Kualitatif dan R\&D. Bandung: Alfabeta, 2012.

[9] W. Zuhaily, Ușūl al- Fiqh al- Islāmī Juz II. Damaskus: Dār al-Fikr, 1986.

[10] N. Muna, "Konsep Isolasi dalam Jaringan Sosial Untuk meminimalisasi Efek Contagious

(Kasus Penyebaran Virus Corona di Indonesia)," J. Sos. Hum. Terap., vol. 2, no. 2, 2020.

[11] J. al-D. M. bin M. bin Mandhūr, , Lisānn al- 'Arab Jilid I. Beirut: Dār Șādir, 2010.

[12] I. I. A. Duny a, Kitāb al-Maraḍ wa al-Kaffarāt. Bombay: Dār Salafiyyah, 1991.

[13] I. A. bin 'Ali bin Hajar Al-Asqalāny, Fath al-Bāri. Cairo: al-Maktabah al-Salafiyy ah, 2015.

[14] A. W. Munawwir, Al- Munawwir Kamus Arab-Indonesia. Yogyakarta: Pustaka Progressif, 1984.

[15] 'Ali Ahmad Al-Nadwi, al-Qawā'id al-Fiqhiyyah. Damaskus: Dār al-Qalam, 1998.

[16] M. A. A.- Zarqa, Hukum Islam dan Perubahan Sosial. Jakarta: Rineka Cipta, 2000.

[17] N. Haroen, Ushul Fiqih I. Jakarta: Wacana Ilmu, 2007.

[18] S. al-D. A. ibn I. al- Qarāfì, Sharh Tanqīh al- Fuṣūl fì 'Ilm al- Ușūl. Makkah: Markāz alDirāsāt al- Islāmiyyah Jāmi'ah Umm al- Qurā.

[19] M. ibn A. B. ibn A. ibn al-Q. al- Jawziy yah, I'lām al- Muwaqqi'īn 'an Rabb al- 'Alamìn Juz III. Beirut: Dār al- kutūb al- 'Ilmiy ah, 1991.

[20] T. I. T. al- Harrani, Majmū' al- Fatāwā Juz XXIII. Madinah: Majma' al- Fahd, 1996.

[21] H. M. Noor, Interview. 05082020.

[22] K. Idris, Interview. 15082020.

[23] Wildan, Interview. 06082020.

[24] Kiki, Interview. 08082020.

[25] Faiz, Interview. 10082020.

[26] Eko, Interview. 07082020.

[27] Warnoto, Interview. 12082020.

[28] Hilmy, Interview. 04082020.

[29] Mahsun, Interview. 11082020.

[30] Najih, Interview. 14082020.

[31] H. Tjahjono, Interview. 15082020. 